\title{
Development of Entrepreneurial Initiatives in Agricultural Business: A Methodological Approach
}

\author{
By Lesia Kucher ${ }^{1}$, Sviatoslav Kniaz ${ }^{2}$, Olena Pavlenko ${ }^{3}$, Olesya Holovina ${ }^{3}$, \\ Oksana Shayda ${ }^{2}$, Ihor Franiv ${ }^{4}$, Vasyl Dzvonyk ${ }^{2}$
}

\begin{abstract}
The purpose of the study is to improve the methodological approach to taking into account critical factors for the development of entrepreneurial initiatives in agribusiness. To achieve this goal, it is necessary to: identify factors influencing the development of entrepreneurial initiatives in agribusiness; perform classification and analysis of factors in order to identify those that are critical for the development of entrepreneurial initiatives in agribusiness; specify the stages of the methodological approach to taking into account critical factors for the development of entrepreneurial initiatives in agribusiness. It is argued that entropy in the agribusiness environment can be caused by the fact that when forming decisions related to the development of entrepreneurial initiatives, the relationship between critical factors and their nature is not taken into account. It is proved that critical for the development of entrepreneurial initiatives in agribusiness are factors that are related to each other both on the basis of similarity of structure and on the basis of similarity of values that characterize these factors. It is argued that entrepreneurial initiatives in agribusiness should be based on in-depth factor analysis, the results of which exclude fluctuations in the implementation of these initiatives and prevent entropy.
\end{abstract}

Keywords: agribusiness, factors, entrepreneurial initiative, cluster analysis.

\section{Introduction}

The peculiarities of the emergence and implementation of entrepreneurial initiatives in agribusiness are primarily due to the fact that the agricultural market belongs to the raw materials sector of the economy and a significant part of agribusiness entities are exporters. Given this, the list of the factors that affect the effectiveness of entrepreneurial initiatives of agribusiness entities is quite extensive. In this case, the concept of "entrepreneurial initiatives" is interpreted as an activity to start new projects or develop existing ones in the agricultural sector of the economy accompanied by creating new jobs, increasing the volume and range of agricultural production, developing logistics, etc., making a profit and increasing the market value of assets. Recently, international economic organizations and influential rating agencies have been predicting that due to the pandemic and the complication of transfer between countries, the volume of trade in agricultural products will fall, and prices will decline. The Ukrainian producers of agricultural products in 2020 already understood the importance of these circumstances, as the export of domestic agricultural products decreased by

\footnotetext{
${ }^{1}$ Kharkiv National Agrarian University named after V. V. Dokuchayev, Kharkiv, Ukraine

${ }^{2}$ Lviv Polytechnic National University, Lviv, Ukraine

${ }^{3}$ Odesa State Environmental University, Odesa, Ukraine

${ }^{4}$ V. I. Vernadsky Taurida National University, Kyiv, Ukraine
} 
$10.8 \%$ compared to 2019 . As a result, the production of plant products decreased by $13.9 \%$ and the production of livestock products by $2.6 \%$. The organization for Economic Cooperation and Development has already identified the trend of decreasing world prices for such important export goods for Ukraine such as: oilseeds and vegetable oil, pork, lamb, wheat, corn, barley. Taking into account the high credit rates on bank loans, and the reduction of export quotas for exports to the EU, which Ukraine uses in full, in particular, for honey, sugar, cereals, flour, starch, processed tomatoes, grape and apple juices, corn, poultry, etc., which significantly weakens the position of domestic agribusiness entities and increases the likelihood of entropy phenomena. As a result, the relevance of scientifically based, systematic research of the factors that are critical for the development of entrepreneurial initiatives in agribusiness is increasing.

In the scientific literature, quite a lot of attention is paid to the problems of entrepreneurship, in particular, the launch of startups, optimization of business processes, and the development of entrepreneurial initiatives. From the perspective of factor analysis, it is a component of the process of making entrepreneurial decisions; these problems can be divided into several groups, namely, concerning:

- methodological problems of factor analysis. In this direction, M. V. Watkins [39], M. Alavi, D. Visentin, D. Thapa, G. Hunt, R. Watson, M. Cleary [2]; A. Burlakov, I. Mushenyk [6];

- grouping factors. This problem is covered by the research of such authors as: T. Curlin, M. Pejić Bach and I. Miloloža [8]; J. Chen, L. Yang, Z. Qian et al. [7], Z. Hloušková, M. Lekešová [12], H. E. Garcia Lopes, M. de Sevilha [10], D. Pavelkova, M. Zizka, L. Homolka, A. Knapkova, N. Pelloneova [29], M. Bennasar-Veny, A. Yañez, J. Pericas, L. Ballester, J. Fernandez-Dominguez, P. Tauler, A. Aguilo [4];

- approaches to identifying the causes of entrepreneurial, managerial, and engineeringtechnological problems. In this context, it is appropriate to mention S. Majaro [21], A. Goel, L. S. Ganesh, A. Kaur [11], I. Johansen [14], R. Navrátil, Y. Brodrechtová, R. Sedmák, J. Tuček [24], M. Osondu, O. Prokhorenko [26];

- assessing the current state of the enterprise and forecasting its changes based on identified factors (M. Sitnicki, I. Netreba [34], S. Kniaz, S. Stasishyn, M.-O. Syzon, S. Stasevych, A. Terebukh, B. Pshyk, Ya. Bohiv, O. Druhov [18]), A. Sumets, M. Serbov, R. Skrynkovskyy, V. Faldyna, K. Satusheva [36], A. Sumets, S. Kniaz, N. Heorhiadi, O. Farat, R. Skrynkovskyy, V. Martyniuk [35], S. Kniaz, A. Shchebel, O. Mrykhina, O. Pavlenko, Y. Bohiv, O. Kalashnyk, S. Moroz, O. Kyrychenko, B. Kushka I. Pastyrska and V. Dzvonyk [17], Yu. Kernasyuk [16], V. Vedeneev [37], O. Mykhaylenko, I. Khilchenko [23], D. Akullo, H. Maat, A. E. J. Wals [1], N. Maknickiené, J. Stankevičienè, A. Maknickas [22], A. Sbardella, E. Pugliese, A. Zaccaria, P. Scaramozzino [32], P. Galvin [9], D. Wardhana, R. Ihle, W. Heijman [38], A. H. Berdiyev, M. K. Dustova [5], K. C. Saban Kumar, P. Arun Kumar Timalsina [31]. Issues of development of agricultural enterprises and agribusiness in general are considered in the publications of Z. Bednarikova, M. Bavorova, E. Ponkina [3], L. Hudáková Stašová [13], A. Karnaushenko et al. [15], O. Kravchenko et al. [19], V. Nitsenko et al. [25], T. Pasichnyk, A. Kucher, R. Khirivskyi [27], N. Patyka et al. [28], J. Rogito et al. [30], A. Shevchenko, O. Petrenko [33].

Judging by the analysis of literature sources, there is reason to assert that the problem of 
taking into account the factors critical for the development of entrepreneurial initiatives in agribusiness has now been studied rather fragmentally, not systematically.

\section{Materials and Methods}

The purpose of the paper is to improve the methodological approach to taking into account the factors critical for the development of entrepreneurial initiatives in agribusiness. To achieve this goal, it is necessary to:

- identify the factors that affect the development of entrepreneurial initiatives in agribusiness;

- perform classification and analysis of the factors in order to identify those that are critical for the development of entrepreneurial initiatives in agribusiness;

- specify the stages of the methodological approach to taking into account the factors critical for the development of entrepreneurial initiatives in agribusiness.

During the study, the method of content analysis and the method of expert assessments were used to identify factors influencing the development of entrepreneurial initiatives in agribusiness. Methods of isomorphic and isotonic cluster analysis are used to construct the classification and study of factors on alternative grounds; the method of graphic modeling and elements of set theory were used during the selection of stages of the methodical approach to taking into account critical factors for the development of entrepreneurial initiatives in agribusiness.

\section{Results}

Based on the above literature sources studying by the content analysis method, it is revealed that the source of unpredictable fluctuations that can cause entropy in the agribusiness environment is primarily environmental factors, in particular such as: lower prices, reduced demand, complication of Transportation Logistics, introduction of tariff and non-tariff barriers in trade in agricultural products, etc. At the same time, these factors mainly belong to the category of non-regulated agribusiness entities, that is, they require adaptation to themselves. Given this, the subjects of interest in this field are the factors that can be influenced by agribusiness entities. These are factors such as:

1) the level of awareness of agribusiness entities about changes in the market environment;

2) the responsiveness of persons responsible for decision-making to prevent and correct undesirable situations;

3) the level of conservatism in implementing strategic and tactical development plans;

4) the level of analytical support for the decision-making process aimed at solving entrepreneurial, managerial and engineering-technological problems;

5) the level of resistance to changes in organizations where management plans to optimize business and technological processes of production;

6) the level of orientation in regulatory legal acts regulating activities in the field of agribusiness;

7) the level of development of management systems of agricultural enterprises;

8) the availability of qualified personnel capable of preparing financial and technical 
documentation accompanying business projects with the financial participation of international funds and banks at the proper level;

9) the belonging of agricultural enterprises to statutory or associated associations in the field of agribusiness;

10) the share of creatively active employees in the total number of agricultural enterprises;

11) the orientation level of the agricultural enterprise to the consumer;

12) the policy of the agricultural enterprise regarding its role in implementing the principles of sustainable development.

To analyze these factors and identify those that are critical for the development of entrepreneurial initiatives in agribusiness, the expert survey method is applied, and the obtained results are processed using cluster analysis. The selection of experts was based on such criteria as the presence of a senior position; work experience in a senior position at least three years; consent to participate in the survey. Based on these criteria, the potential respondents were selected and those who agreed to participate in the survey were identified. The basis is an error of 0.15 , and a confidence probability of 0.95 . The number of respondents worth interviewing is calculated with the formula: $x=\left(q(1-q) / p_{y}^{2}\right) t^{2} \approx 10$,

where

the ratio of the share of people who agreed to the survey and meet other criteria to the total number of selected experts;

the student's criterion for the selected level of the confidence interval;

the average marginal error of the share.

In order the error of the results not to exceed the permissible limits of $15 \%$, it was necessary to interview 10 respondents.

To perform cluster analysis, the Microsoft Excel IFR specifications - clast_izomorf_trek and clast_izoton_trek is used. The first of the specifications will allow grouping the factors according to the similarity of their structure, and the second one according to the similarity of values that characterize these factors. To perform this task, the method of isomorphic grouping and isotonic grouping is used, which is thoroughly described in C. Lapachem, A. Chubenko and P. Babich [20]:

- performing isomorphic grouping:

$$
Z_{i j}=\frac{X_{i j} / \sum_{i=1}^{n} X_{i j}}{\sum_{j=1}^{m} \frac{X_{i j}}{\sum_{i=1}^{n} X_{i j}}},
$$

where is the value of the $j$-th attribute for the $i$-th object.

- the determination of the isomorphic distance:

$d_{i k}=\sqrt{\sum_{j=1}^{m}\left(\mathbf{Z}_{i j}-\mathbf{Z}_{k j}\right)^{2}}$.

- the selection of a critical point: 
$C_{l}(\mathrm{p})=\frac{1}{K} \sum_{l=1}^{G} \sum_{p=1}^{P_{1}} C_{l}(\mathrm{p})$

where

$$
C_{l}(\mathrm{p})=\min _{q \in g_{1}} C_{l l}(\mathrm{p}, \mathrm{q}), \mathrm{p}=1,2 \ldots \mathrm{P}_{l}, K=\sum_{l=1}^{G} P_{l} ;
$$

$C_{l l}(\mathrm{p}, \mathrm{q})-$ distance between factors $p \mathrm{i} q$ that belong to the l-th cluster;

$C_{l}(\mathrm{p})$ - the distance between factor $\mathrm{p}$ and a neighboring factor in cluster $l$;

$\mathrm{Pi}$ - number of factors in cluster $l$;

$G$ - the number of clusters;

- the normalization of scales by replacing each feature of the factor with a value obtained by the formula:

$$
V_{i j}=\frac{X_{i j}}{\sum_{i=1}^{n} X_{i j}},
$$

where, $X_{i j}$ is the value of the $j$-th attribute of the $i$-th factor.

- the determination of the values of each factor

$w_{i}=\sum_{j=1}^{m} V_{i j}$

- the determination of the distances between the factors

$d_{i j}=\left|\omega_{i}-\omega_{j}\right|$.

Table 1 shows the primary data matrix, which represents the distribution of respondents' scores between factors. Experts were asked to rate the significance of 12 factors on a scale from 10 to 100 points, where 10 points is the minimum score, and 100 points is the maximum.

\begin{tabular}{|c|c|c|c|c|c|c|c|c|c|c|}
\hline 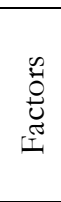 & $\begin{array}{l}\tilde{0} \\
0 \\
0 \\
\dot{\sigma} 0\end{array}$ & 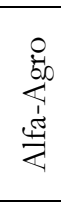 & 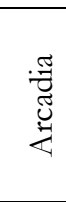 & 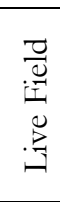 & 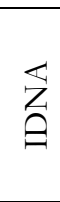 & 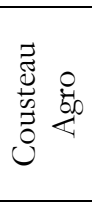 & 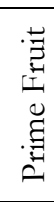 & 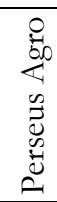 & 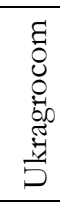 & 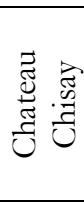 \\
\hline 1 & 10 & 80 & 80 & 40 & 40 & 30 & 90 & 40 & 40 & 40 \\
\hline 2 & 30 & 90 & 90 & 50 & 50 & 40 & 40 & 50 & 50 & 50 \\
\hline 3 & 30 & 90 & 90 & 20 & 60 & 20 & 50 & 20 & 60 & 20 \\
\hline 4 & 40 & 40 & 100 & 10 & 50 & 100 & 10 & 50 & 90 & 100 \\
\hline 5 & 20 & 50 & 90 & 30 & 50 & 90 & 30 & 50 & 40 & 90 \\
\hline 6 & 10 & 20 & 70 & 30 & 40 & 70 & 30 & 40 & 50 & 70 \\
\hline 7 & 30 & 40 & 80 & 60 & 30 & 80 & 40 & 40 & 40 & 40 \\
\hline 8 & 40 & 50 & 80 & 50 & 60 & 90 & 50 & 50 & 50 & 50 \\
\hline 9 & 50 & 60 & 90 & 40 & 50 & 90 & 20 & 60 & 20 & 60 \\
\hline 10 & 20 & 50 & 90 & 70 & 40 & 40 & 80 & 60 & 30 & 80 \\
\hline 11 & 20 & 50 & 90 & 30 & 50 & 90 & 30 & 50 & 40 & 90 \\
\hline 12 & 10 & 20 & 70 & 30 & 40 & 70 & 30 & 40 & 50 & 70 \\
\hline
\end{tabular}

Table 1: Expert assessments and points

Source: created by the authors. 
The obtained matrix is necessary to determine the isomorphic and isotonic distances between the studied factors. Using the above specifications of the Microsoft Excel PPP, these matrices will be created (Table 2).

The constructed matrices are necessary to identify the so-called critical points that will divide the studied set of factors into groups. This task is performed by finding the minimum values between the factors and selecting the maximum value among these minimum ones This very value will be critical.

Table 2: Matrix of distance

\begin{tabular}{|c|c|c|c|c|c|c|c|c|c|c|c|c|}
\hline \multicolumn{13}{|c|}{ Isomorphic distance matrix } \\
\hline & 1 & 2 & 3 & 4 & 5 & 6 & 7 & 8 & 9 & 10 & 11 & 12 \\
\hline 1 & 0 & 0.152 & 0.166 & 0.293 & 0.207 & 0.210 & 0.192 & 0.184 & 0.253 & 0.125 & 0.207 & 0.210 \\
\hline 2 & 0.152 & 0 & 0.123 & 0.198 & 0.134 & 0.164 & 0.119 & 0.104 & 0.139 & 0.139 & 0.134 & 0.164 \\
\hline 3 & 0.166 & 0.123 & 0 & 0.231 & 0.208 & 0.229 & 0.206 & 0.169 & 0.215 & 0.220 & 0.208 & 0.229 \\
\hline 4 & 0.293 & 0.198 & 0.231 & 0 & 0.134 & 0.143 & 0.200 & 0.167 & 0.174 & 0.262 & 0.134 & 0.143 \\
\hline 5 & 0.207 & 0.134 & 0.208 & 0.134 & 0 & 0.077 & 0.134 & 0.110 & 0.130 & 0.162 & 0 & 0.077 \\
\hline 6 & 0.210 & 0.164 & 0.229 & 0.143 & 0.077 & 0 & 0.140 & 0.127 & 0.185 & 0.161 & 0.077 & 0 \\
\hline 7 & 0.192 & 0.119 & 0.206 & 0.200 & 0.134 & 0.140 & 0 & 0.071 & 0.129 & 0.129 & 0.134 & 0.140 \\
\hline 8 & 0.184 & 0.104 & 0.169 & 0.167 & 0.110 & 0.127 & 0.071 & 0 & 0.104 & 0.142 & 0.110 & 0.127 \\
\hline 9 & 0.253 & 0.139 & 0.215 & 0.174 & 0.130 & 0.185 & 0.129 & 0.104 & 0 & 0.199 & 0.130 & 0.185 \\
\hline 10 & 0.125 & 0.139 & 0.220 & 0.262 & 0.162 & 0.161 & 0.129 & 0.142 & 0.199 & 0 & 0.162 & 0.161 \\
\hline 11 & 0.207 & 0.134 & 0.208 & 0.134 & 0 & 0.077 & 0.134 & 0.110 & 0.130 & 0.162 & 0 & 0.077 \\
\hline 12 & 0.210 & 0.164 & 0.229 & 0.143 & 0.077 & 0 & 0.140 & 0.127 & 0.185 & 0.161 & 0.077 & 0 \\
\hline \multicolumn{13}{|c|}{ Isotonic distance matrix } \\
\hline & 1 & 2 & 3 & 4 & 5 & 6 & 7 & 8 & 9 & 10 & 11 & 12 \\
\hline 1 & 0 & 0.091 & 0.037 & 0.119 & 0.029 & 0.138 & 0.010 & 0.150 & 0.086 & 0.123 & 0.029 & 0.138 \\
\hline 2 & 0.091 & 0 & 0.128 & 0.028 & 0.061 & 0.229 & 0.101 & 0.059 & 0.004 & 0.032 & 0.061 & 0.229 \\
\hline 3 & 0.037 & 0.128 & 0 & 0.156 & 0.066 & 0.101 & 0.026 & 0.187 & 0.123 & 0.161 & 0.06 & 0.101 \\
\hline 4 & 0.119 & 0.028 & 0.156 & 0 & 0.090 & 0.257 & 0.129 & 0.031 & 0.032 & 0.004 & 0.090 & 0.257 \\
\hline 5 & 0.029 & 0.061 & 0.066 & 0.090 & 0 & 0.167 & 0.039 & 0.121 & 0.057 & 0.094 & 0 & 0.167 \\
\hline 6 & 0.138 & 0.229 & 0.101 & 0.257 & 0.167 & 0 & 0.127 & 0.289 & 0.225 & 0.262 & 0.167 & 0 \\
\hline 7 & 0.010 & 0.101 & 0.026 & 0.129 & 0.039 & 0.127 & 0 & 0.161 & 0.097 & 0.134 & 0.039 & 0.127 \\
\hline 8 & 0.150 & 0.059 & 0.187 & 0.031 & 0.121 & 0.289 & 0.161 & 0 & 0.064 & 0.026 & 0.121 & 0.289 \\
\hline 9 & 0.086 & 0.004 & 0.123 & 0.032 & 0.057 & 0.225 & 0.097 & 0.064 & 0 & 0.037 & 0.057 & 0.225 \\
\hline 10 & 0.123 & 0.032 & 0.161 & 0.004 & 0.094 & 0.262 & 0.134 & 0.026 & 0.037 & 0 & 0.094 & 0.262 \\
\hline 11 & 0.029 & 0.061 & 0.066 & 0.090 & 0 & 0.167 & 0.039 & 0.121 & 0.057 & 0.094 & 0 & 0.167 \\
\hline 12 & 0.138 & 0.229 & 0.101 & 0.257 & 0.167 & 0 & 0.127 & 0.289 & 0.225 & 0.262 & 0.167 & 0 \\
\hline
\end{tabular}

Source: created by the authors.

Thus, in the matrix of isomorphic distances, the minimum values are: between 1 and 10 factors - 0,125; between 2 and 8 factors - 0.104; between 3 and 2 factors - 0.123; between 4 and 5 factors $-0.134 ; 5$ and 12 factors -0.077 ; between 6 and 5 factors 0.077 ; 7 and 8 factors -0.071 ; between 8 and 7 factors -0.071 ; between 9 and 8 factors - 0.104; between 10 and 1 factors - 0.125; between 11 and 6 factors -0.077 ; between 12 and 5 factors -0.077 . According to the isomorphic distance matrix, the maximum distance between 4 and 5 factors is 0.134 . In its turn, according to the matrix of isotonic 
distances, the minimum ones are between 1 and 7 factors -0.010 ; between 2 and 9 factors -0.004601 ; between 3 and 7 factors -0.026 ; between 4 and 10 factors -0.004 ; between 5 and 1 factors -0.0293 ; between 6 and 3 factors -0.101 ; between 7 and 1 factors -0.010 ; between 8 and 7 factors -0.026 ; between 9 and 2 factors -0.004 ; between 10 and 4 factors -0.004 ; between 11 and 1 factors -0.029 ; between 12 and 3 factors -0.101 . Of the above minimum distances, the maximum distances are between 6 and 3 factors -0.101 , as well as between 12 and 3 factors -0.101 .

Based on the obtained minimum distances between factors and critical points, it is possible to build clusters (Fig. 1-2). As we can see, three clusters were formed based on the isomorphic breakdown of the studied population into factors, and four clusters were formed based on the isotopic breakdown. To enhance the information content of the analysis, it is also advisable to construct dendrites, that is, tree-like structures that show relationships between the factors. To do this, the same Microsoft Excel PPP specifications will be used. Below there are the formed chains based on the minimum distances between factors. The minimum distances from the matrices given in Table 2 formed a different number of chains and chains are different in composition. This indicates that isomorphic and isotonic dendrites will be different. Due to the fact that clast_izomorf_trek and clast_izoton_trek, in addition to chains of factors, also, creates matrices of inter-chain distances (Table 3-4), dendrites will be created (Fig. 3-4).

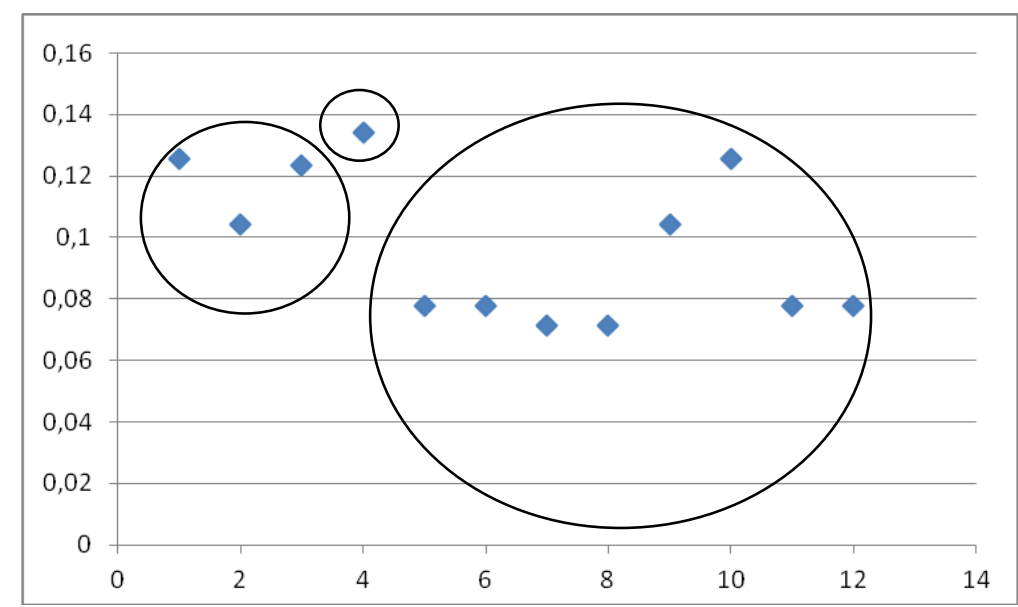

Figure 1: Clusters based on isomorphic distances.

Notes: at vertical - isomorphic values between factors; at horizontal - the ordinal numbers of factors.

Source: created by the authors. 


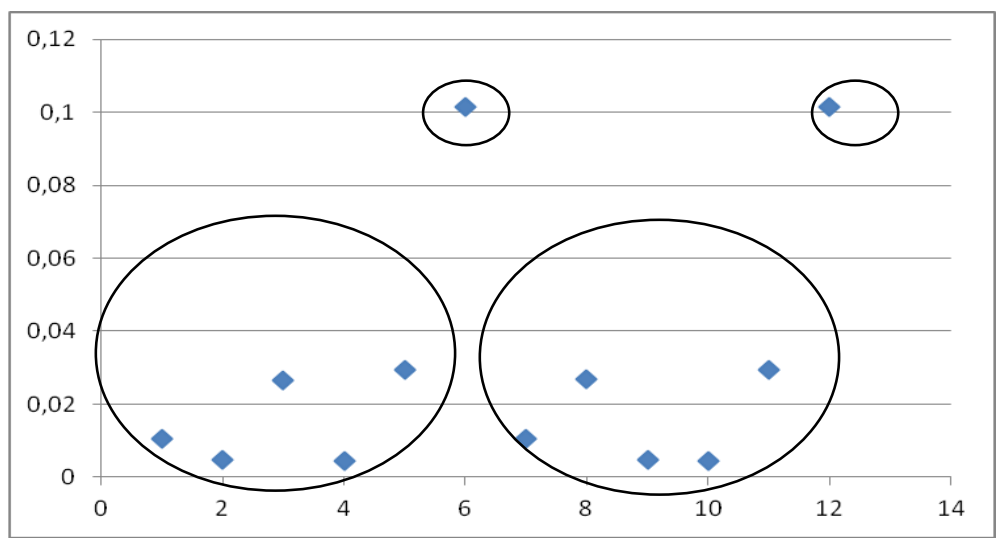

Figure 2: Clusters based on isotonic distances.

Notes: at vertical - isomorphic values between factors; at horizontal - the ordinal numbers of factors.

Source: created by the authors.

Chains formed based on isomorphic distances:

Chain 1 (2):

Chain 2 (5):

Chain 3 (3):

Chain 4 (2):

\begin{tabular}{|c|c|c|c|c|}
\hline 1 & 0.125 & 10 & \multirow[b]{2}{*}{0.169} & \\
\hline 2 & 0.104 & 8 & & 3 \\
\hline 4 & 0.134 & 5 & 0 & 11 \\
\hline 6 & 0 & 12 & & \\
\hline Chains & ned bas & on & nic dist & ces: \\
\hline 1 & 0.010 & 7 & 0.026 & 3 \\
\hline 2 & 0.004 & 9 & & \\
\hline 4 & 0.004 & 10 & 0.026 & 8 \\
\hline 5 & 0 & 11 & & \\
\hline 6 & 0 & 12 & & \\
\hline
\end{tabular}

Chain 1 (3):

Chain 2 (2):

Chain 3 (3):

Chain 4 (2):

Chain 5 (2):

As seen in the Table 3, the first chain is connected to the second one by factors 10 and 7 , the second and third ones are connected by factors 8 and 5 , the third and fourth ones are connected by factors 5 and 6 .

Table 3: Isomorphic matrix of inter-chain distances

\begin{tabular}{|c|c|c|c|c|}
\hline $\begin{array}{c}\text { The ordain numbers of } \\
\text { the chains }\end{array}$ & 1 & 2 & 3 & 4 \\
\hline \multirow{2}{*}{1} & 0 & 0.129 & 0.162 & 0.161 \\
\cline { 2 - 5 } & $\mathbf{( 0 ; 0 )}$ & $(10 ; 7)$ & $(10 ; 5)$ & $(10 ; 6)$ \\
\hline \multirow{2}{*}{2} & 0.129 & 0 & 0.110 & 0.127 \\
\hline \multirow{2}{*}{3} & $(10 ; 7)$ & $\mathbf{( 0 ; 0 )}$ & $(8 ; 5)$ & $(8 ; 6)$ \\
\cline { 2 - 5 } & 0.162 & 0.110 & 0 & 0.077 \\
\hline \multirow{2}{*}{4} & $(10 ; 5)$ & $(8 ; 5)$ & $\mathbf{( 0 ; 0 )}$ & $(5 ; 6)$ \\
\hline & 0.161 & 0.127 & 0.077 & 0 \\
\hline \multirow{2}{*}{$\begin{array}{c}\text { Minimum distances } \\
\text { between chains }\end{array}$} & $(10 ; 6)$ & $(8 ; 6)$ & $(5 ; 6)$ & $\mathbf{( 0 ; 0 )}$ \\
\cline { 2 - 5 } & 0.129 & 0.110 & 0.077 & 0.077 \\
\hline
\end{tabular}

Source: created by the authors. 
In turn, judging by Table 4, the first chain is connected to the fourth and fifth ones by factors 1 and 5 and 3 and 6 . The second chain is connected to the third one by factors 2 and 4.

Table 4: Isotonic matrix of inter-chain distances

\begin{tabular}{|c|c|c|c|c|c|}
\hline $\begin{array}{c}\text { The ordain numbers } \\
\text { of the chains }\end{array}$ & 1 & 2 & 3 & 4 & 5 \\
\hline \multirow{2}{*}{1} & 0 & 0.086 & 0.119 & 0.029 & 0.101 \\
\cline { 2 - 6 } & $\mathbf{( 0 ; 0 )}$ & $(1 ; 9)$ & $(1 ; 4)$ & $(1 ; 5)$ & $(3 ; 6)$ \\
\hline \multirow{2}{*}{2} & 0.086 & 0 & 0.028 & 0.057 & 0.225 \\
\cline { 2 - 6 } & $(1 ; 9)$ & $\mathbf{( 0 ; 0 )}$ & $(2 ; 4)$ & $(9 ; 5)$ & $(9 ; 6)$ \\
\cline { 2 - 6 } & 0.119 & 0.028 & 0 & 0.090 & 0.257 \\
\hline \multirow{2}{*}{3} & $(1 ; 4)$ & $(2 ; 4)$ & $\mathbf{( 0 ;} \mathbf{0})$ & $(4 ; 5)$ & $(4 ; 6)$ \\
\cline { 2 - 6 } & 0.029 & 0.057 & 0.090 & 0 & 0.167 \\
\hline \multirow{2}{*}{5} & $(1 ; 5)$ & $(9 ; 5)$ & $(4 ; 5)$ & $\mathbf{( 0 ; 0 )}$ & $(5 ; 6)$ \\
\cline { 2 - 6 } & 0.101 & 0.225 & 0.257 & 0.167 & 0 \\
\hline \multirow{2}{*}{$\begin{array}{c}\text { Minimum distances } \\
\text { between chains }\end{array}$} & $(3 ; 6)$ & $(9 ; 6)$ & $(4 ; 6)$ & $(5 ; 6)$ & $\mathbf{( 0 ; 0 )}$ \\
\cline { 2 - 6 } & 0.0293 & 0.028 & 0.028 & 0.029 & 0.101 \\
\hline \multirow{2}{*}{5}
\end{tabular}

Source: created by the authors.

Consequently, based on the isomorphic breakdown of the studied set of factors, one dendrite was destroyed (see Fig 3), and based on the isotopic breakdown - two dendrites (see Fig. 4.)

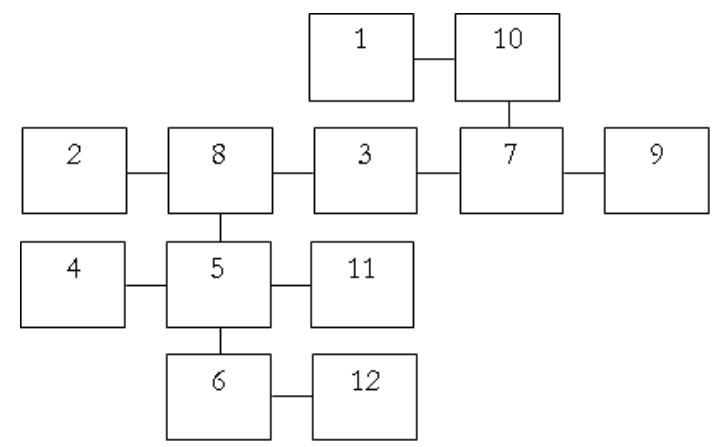

Figure 3: The dendrite is formed because of an isomorphic grouping of the studied set of factors Source: created by the authors.

The results show that the resulting dendrites have pairs of related factors -3 and 7, 5 and 11, 6 and 12, and there are also factors that link these pairs -8 in the isomorphic dendrite and 1 in the isotopic dendrite. The pairs of the factors are related both structurally and to the values that characterize their significance. As a result, when making decisions on the development of entrepreneurial initiatives of agricultural enterprises, it is necessary to take into account the mutual influence of these factors among themselves. 


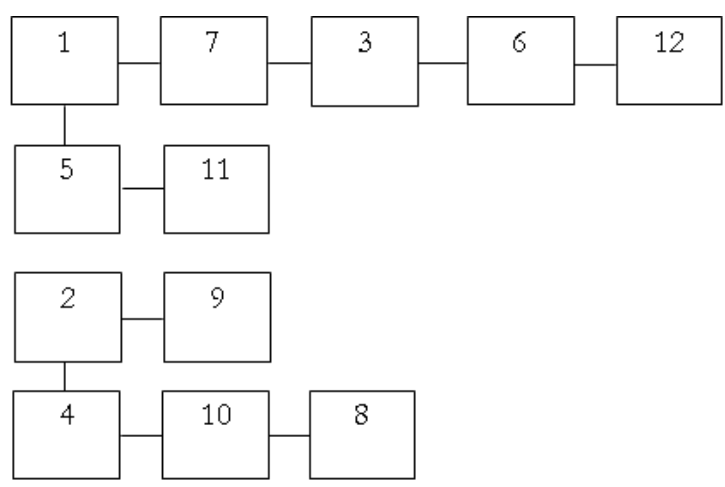

Figure 4: The dendrite formed because of the isotonic grouping of the studied set of factors Source: created by the authors.

The other factors based on the relationships shown in Fig. 3-4 should be taken into account. As a result of this research, the following sequence of the factors is proposed when making the decisions aimed at developing entrepreneurial initiatives Agroset, AlfaAgro, Arcadia, Live Field, IDNA, Cousteau Agro, Prime Fruit, Perseus Agro, Ukragrocom, Chateau Chisay (Fig. 5).

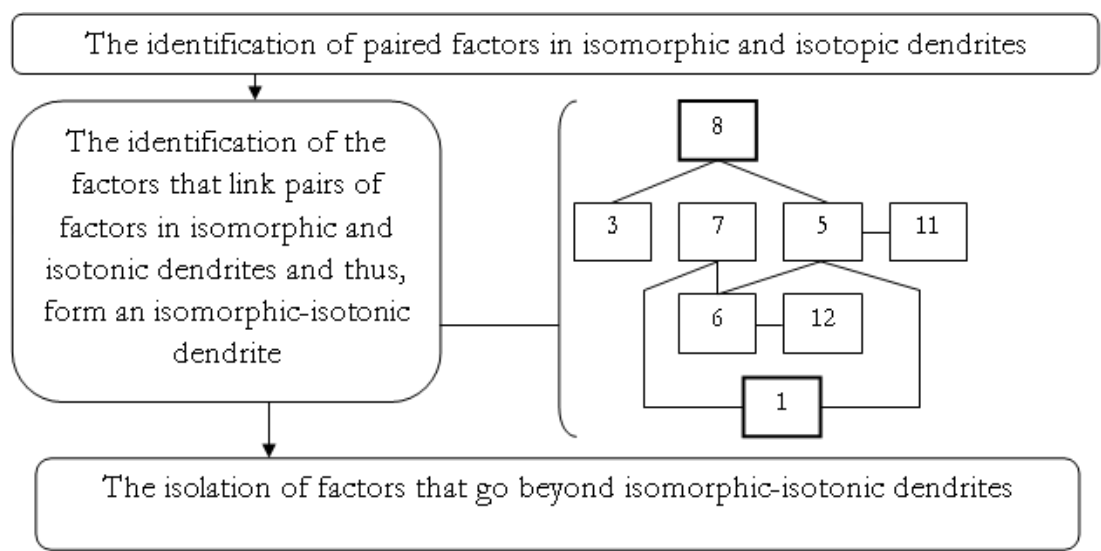

Figure 5: The sequence of stages of the proposed methodological approach to taking into account the factors critical for the development of entrepreneurial initiatives in agribusiness

Source: created by the authors.

Let us consider the proposed methodological approach through the prism of the provisions of set theory to prove the logic of analysis. To do this, the axioms of union and intersection of sets are applied. First, for convenience, the ordinal numbers of the analyzed factors are marked in Latin letters. So, $1-\mathrm{A}, 2-\mathrm{B}, 3-\mathrm{C}, 4-\mathrm{D}, 5-\mathrm{E}, 6-\mathrm{F}$, $7-\mathrm{G}, 8-\mathrm{H}, 9-\mathrm{I}, 10-\mathrm{J}, 11-\mathrm{K}, 12-\mathrm{L}$. These factors form a certain set $A \cup \ldots \cup L \subset\left\{\begin{array}{c}j=12 \\ X_{i} \\ i=1\end{array}\right\}$.

The resulting set is equivalent to an isomorphic dendrite (see fig. 3), because in it all the 
factors are linearly related to each other. Given this, dendrites that are formed because of isotonic separation of the factors form two other sets that are not equivalent to each other, namely.

$$
\begin{aligned}
& A \cup G \cup C \cup F \cup L \subset\left\{\begin{array}{c}
n=5 \\
Y_{m} \\
m=1
\end{array}\right\} ; \\
& I \cup B \cup D \cup J \cup H \subset\left\{\begin{array}{c}
q=5 \\
Z_{p} \\
p=1
\end{array}\right\} ; \\
& \left\{\begin{array}{c}
n=5 \\
Y_{m} \\
m=1
\end{array}\right\} \cup\left\{\begin{array}{c}
q=5 \\
Z_{p} \\
p=1
\end{array}\right\} \subset \bigcup\left\{\begin{array}{l}
u=5 \\
R_{o} \\
o=1
\end{array}\right\} .
\end{aligned}
$$

To demonstrate the logic of selecting and taking into account the factors critical for the development of entrepreneurial initiatives in agribusiness, it is important to identify them in the structure $\left.\left(\bigcup \begin{array}{c}u=5 \\ R_{o} \\ o=1\end{array}\right\} \wedge\left\{\begin{array}{c}j=12 \\ X_{i} \\ i=1\end{array}\right\}\right) \square \bigcup\left\{\begin{array}{c}t \\ v_{s} \\ s=1\end{array}\right\}$, that is, in combining the sets of dendrites created on the basis of the isomorphic and isotonic grouping of factors. Given this, it is advisable to apply the difference operation over the sets, and thus, to identify the factors that are critical. Therefore,

$$
\begin{aligned}
& \bigcup\left\{\begin{array}{l}
u=5 \\
R_{o} \\
o=1
\end{array}\right\} \backslash\left\{\begin{array}{c}
j=12 \\
X_{i} \\
i=1
\end{array}\right\}=\left\{\begin{array}{c}
\delta \\
\alpha_{\chi} \\
\chi=1
\end{array}\right\} \wedge\left\{\begin{array}{c}
\phi \\
\beta_{\varepsilon} \\
\varepsilon=1
\end{array}\right\} ; \\
& \left\{\begin{array}{l}
\delta \\
\alpha_{\chi} \\
\chi=1
\end{array}\right\} \supset\left\{\begin{array}{l}
(C \wedge G) \square M ; \\
(E \wedge K) \sqcap N ; \\
(F \wedge L) \square O ; \\
A ; \\
H .
\end{array}\right. \\
& \left.\left\{\begin{array}{l}
\phi \\
\beta_{\varepsilon} \\
\varepsilon=1
\end{array}\right\} \supset\left(\bigcup \begin{array}{c}
u=5 \\
R_{o} \\
o=1
\end{array}\right\} \backslash\left\{\begin{array}{c}
j=12 \\
X_{i} \\
i=1
\end{array}\right\}\right) \backslash\left\{\begin{array}{c}
\delta \\
\alpha_{\chi} \\
\chi=1
\end{array}\right\} \Leftrightarrow B \cup D \cup I \cup J .
\end{aligned}
$$

the critical factors are identified $\bigcup\left\{\begin{array}{c}t \\ V_{s} \\ s=1\end{array}\right\}$ out of the subsets. These factors are the intersection points of dendrites, the formation of which occurred according to various signs of similarity of factors. Applying the intersection axiom, the created isomorphicisotonic dendrite is formalized.

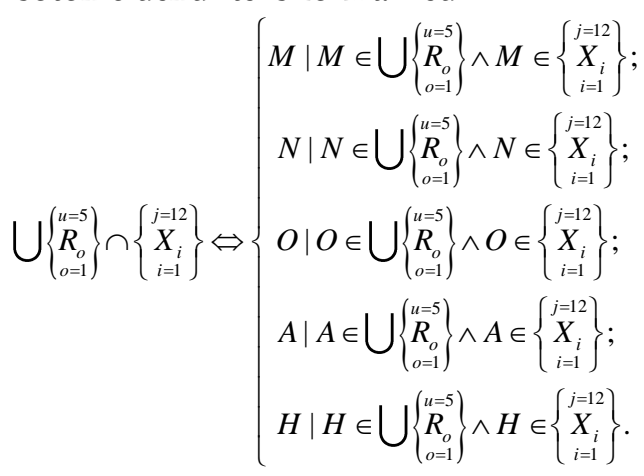

Thus, the isomorphic isotonic dendrite is a set of factors that are linearly related to each 
other. They can cause cause-and-effect relationships, so it is advisable to identify and analyze their totality first, when making decisions related to entrepreneurial initiatives, the experience of which enterprises working in the field of agribusiness do not yet have or it is insignificant.

\section{Conclusions}

According to the results of the study, it is proved that entropy in the agribusiness environment can be caused by a large number of the factors of both internal and external environments, but in the process of making decisions related to the development of entrepreneurial initiatives, the most problematic one is that agribusiness entities do not take into account the relationships between critical factors, as well as the nature of these factors. Among the total number of factors, there are those to which agribusiness entities are forced to adapt and those whose negative impact can be leveled by improving business processes and management systems.

Based on applying the alternative methods of cluster analysis, it is proved that in the general set of factors there is a set of those that are critical for the development of entrepreneurial initiatives. These are the factors that are related both by the similarity of the structure and by the similarity of the values characterizing these factors. These factors include the level of awareness of agribusiness entities about changes in the market environment; the level of conservatism in the implementation of strategic and tactical development plans; the level of resistance to changes in organizations where management plans to optimize business and technological processes of production; the level of orientation in regulatory legal acts that regulate activities in the field of agribusiness; the level of development of management systems of agricultural enterprises; the availability of qualified personnel who are able to properly prepare financial and technical documentation that accompanies business projects with the financial participation of international funds and banks; the level of orientation of the agricultural enterprise to the consumer; the policy of the agricultural enterprise enterprises regarding its role in implementing the principles of sustainable development. It is proved that taking account the factors, which are critical for the development of entrepreneurial initiatives in agribusiness, should be carried out in the following sequence: the identification of pairs of the factors in isomorphic and isotonic dendrites, the identification of the factors connecting pairs of the factors into one, the identification and analysis of the factors that go beyond the isomorphic-isotonic dendrite.

As a result of the research, it is proved that the factors that affect the development of entrepreneurial initiatives in agribusiness should be classified into several characteristics: by the level of relative significance (significant and insignificant), by nature (factors of positive and negative action), by similarity (factors close in structure or values of features that characterize them, and factors not close.) This classification can be used to create data domains that characterize the state of implementing entrepreneurial initiatives, algorithmizing, and automating analytical processes in the management systems of agribusiness entities.

The article develops a methodical approach to taking into account critical factors for the 
development of entrepreneurial initiatives in agribusiness, which is based on the formation of isomorphic-isotonic dendrites, and, unlike existing approaches, avoids entropy caused by unpredictable interactions between critical factors.

The practical value of the improved methodological approach lies in the possibility of its application by agribusiness entities to avoid entropy, which is possible during the launch and implementation of new business projects, especially those accompanied by the development of new agricultural machinery, previously unknown products and technologies for land cultivation and finished agricultural products, etc. The proposed isomorphic-isotonic dendrites, which is the basis of an improved methodological approach, can be successfully applied during strategic and tactical planning of agribusiness enterprises, as well as in the process of making operational management decisions aimed at overcoming market fluctuations.

The further research should be carried out in the direction of monitoring the factors to identify those that are permanent in nature, and whose effect can be predicted. This will allow modeling scenarios of the changes in the conditions in which entrepreneurial initiatives of agribusiness entities are formed and implemented, reasonably.

\section{References}

1. Akullo, D., Maat, H. and Wals, A. E. J. (2019). An institutional diagnostics of agricultural innovation; Public-private partnerships and smallholder production in Uganda. NJAS - Wageningen Journal of Life Sciences, 84: 6-12. https://doi.org/10.1016/i.njas.2017.10.006

2. Alavi, M., Visentin, D. C., Thapa, D. K., Hunt, G. E., Watson, R. and Cleary, M. (2020). Exploratory factor analysis and principal component analysis in clinical studies: Which one should you use? Journal Of Advanced Nursing, 76(8):1886-1889. https://doi.org/10.1111/jan.14377

3. Bednarikova, Z., Bavorova, M. and Ponkina, E. (2020). Entrepreneurial intention of agriculture undergraduates in Russia. Agricultural and Resource Economics, 6(1): 5-22. https://doi.org/10.22004/ag.econ.302965

4. Bennasar-Veny, M., Yañez, A. M., Pericas, J., Ballester, L., Fernandez-Dominguez, J. C., Tauler, P. and Aguilo, A. (2020). Cluster Analysis of Health-Related Lifestyles in University Students. International Journal of Environmental Research and Public Health, 17(5): 1776. https://doi.org/10.3390/ijerph17051776

5. Berdiyev, A. H. and Dustova, M. K. (2020). Advantages of introducing agrocluster in agriculture. International Journal on Orange Technologies, 2(11): 37-40. https://doi.org/10.31149/ijot.v2i11.860

6. Burlakov, A. and Mushenyk, I. (2021). Theoretical Principles of Implementation and Use of Modern Technologies of Intellectual Data Analysis in Economy. Modern Economics, 25: 27-32. https://doi.org/10.31521/modecon.V25(2021)-04.

7. Chen, J., Yang, L., Qian, Z. et al. (2020). Cluster analysis of differences in medical economic burden among residents of different economic levels in Guangdong Province, China. BMC Health Services Research, 20: 988. https://doi.org/10.1186/s12913-020-05817-y

8. Ćurlin, T., Pejić Bach, M. and Miloloža, I. (2020). Presentation skills of business and economics students: Cluster analysis. Croatian Review of Economic, Business and Social Statistics, 6(2): 27-42. https://doi.org/10.2478/crebss-2020-0009

9. Galvin, P. (2019). Local government, multilevel governance, and cluster based innovation policy: Economic cluster strategies in Canada's city regions. Canadian Public Administration, 62: 122-150. https://onlinelibrary.wiley.com/doi/full/10.1111/capa.12314

10. Garcia Lopes, H. E. and de Sevilha Gosling, M. (2021). Cluster Analysis in Practice: Dealing with Outliers in Managerial Research. Revista de Administração Contemporânea, 25(1). https://doi.org/10.1590/1982-7849rac2021200081

11. Goel, A., Ganesh, L. S. and Kaur, A. (2019). Sustainability integration in the management of construction projects: A morphological analysis of over two decades' research literature. Journal of Cleaner 
Production, 236: 0959-6526. https://doi.org/10.1016/i.jclepro.2019.117676

12. Hloušková, Z. and Lekešová, M. (2020). Farm outcomes based on cluster analysis of compound farm evaluation. Agricultural Economics - Czech, 66: 435-443. https://doi.org/10.17221/273/2020AGRICECON

13. Hudáková Stašová, L. (2020). Statistical analysis of suitability of the activity based costing method in agricultural enterprises. Agricultural and Resource Economics, 6(4): 20-42. https://doi.org/10.51599/are.2020.06.04.02

14. Johansen, I. (2018). Scenario modelling with morphological analysis. Technological Forecasting and Social Change, 126: 116-125. https://doi.org/10.1016/j.techfore.2017.05.016

15. Karnaushenko, A., Petrenko, V., Tanklevska, N., Borovik, L. and Furdak, M. (2020). Prospects of youth agricultural entrepreneurship in Ukraine. Agricultural and Resource Economics, 6(4), 90-117. https://doi.org/10.51599/are.2020.06.04.06

16. Kernasyuk, Y. V. (2019). Forecast of the agricultural sector of the economy using artificial neural networks. Bulletin of Agricultural Science, 97(6): 75-81. https://doi.org/20.31073/agrovisnyk201906-11

17. Kniaz, S., Shchebel, A., Mrykhina, O., Pavlenko, O., Bohiv, Y., Kalashnyk, O., Moroz, S., Kyrychenko, O., Kushka, B., Pastyrska, I. and Dzvonyk. V. (2020). Factor analysis of the rationality of enterprise potential management in the coordinate system of organizational development. ARCTIC, 73(9): 227. https://www.arcticjournal.org/show.php? $\mathrm{v}=73 \& \mathrm{i}=9$

18. Kniaz, S., Stasishyn, S., Syzon, M.-O., Stasevych, S., Terebukh, A., Pshyk, B., Bohiv, Ya. and Druhov, O. (2019). Resistance to Change and Market Challenges in the Corporate Governance System. Proceedings of the 34th International Business Information Management Association (IBIMA), 13-14 November 2019, Madrid, Spain, pp. 6922-6928. https://ibima.org/accepted-paper/resistance-to-change-andmarket-challenges-in-the-corporate-governance-system/

19. Kravchenko, O., Kucher, A., Hełdak, M., Kucher, L. and Wysmułek, J. (2020). Socio-economic transformations in Ukraine towards the sustainable development of agriculture. Sustainability, 12(13): 5441. https://doi.org/10.3390/su12135441

20 Lapach, S. N., Chubenko, A. V. and Babich, P. N. (2002), Statistics in science and business. Kyiv, MORION, $640 \mathrm{p}$.

21. Majaro, S. (1988). Morphological analysis. Marketing Intelligence \& Planning, 6(2): 4-11. https://doi.org/10.1108/eb045762

22. Maknickienė, N., Stankevičiené, J. and Maknickas, A. (2020). Comparison of Forex Market Forecasting Tools Based on Evolino Ensemble and Technical Analysis Indicators. Romanian Journal of Economic Forecasting, 23(3): 134-148. http://www.ipe.ro/rjef/rjef3 20/rjef3 2020p134-148.pdf

23. Mykhaylenko, O. V. and Khilchenko, I. Y. (2019). Agrarian sector of Ukraine: current status, problems and prospects of reforming the industry. Modern Economics, 15: 148-152. https://doi.org/10.31521/modecon.V15(2019)-21

24. Navrátil, R., Brodrechtová, Y., Sedmák, R. and Tuček, J. (2019). Forest management scenarios modelling with morphological analysis - examples taken from Podpolanie and Kysuce. Central European Forestry Journal, 65(2): 103-120. https://doi.org/10.2478/forj-2019-0009

25. Nitsenko, V., Mardani, A., Streimikis, J., Ishchenko, M., Chaikovsky, M., Stoyanova-Koval, S. and Arutiunian, R. (2019). Automatic Information System of Risk Assessment for Agricultural Enterprises of Ukraine. Montenegrin Journal of Economics, 15(2): 139-152. https://doi.org/10.14254/1800-5845/2019.15-2.11

26. Osondu, M. and Prokhorenko, O. (2020). Organizational development concept definition: historical aspect and morphological analysis. International scientific journal "Internauka". Series: "Economic Sciences", 11. https://doi.org/10.25313/2520-2294-2020-11-6570

27. Pasichnyk, T. V., Kucher, A. V. and Khirivskyi, R. P. (2016). Efficiency of agricultural enterprises of various organizational and legal forms and the size of land use. Actual problems of economics, 1: 399405.

28. Patyka, N., Gryschenko, O., Kucher, A., Hełdak, M. and Raszka, B. (2021). Assessment of the degree of factors impact on employment in Ukraine's agriculture. Sustainability, 13(2): 564. https://doi.org/10.3390/su13020564

29. Pavelkova, D., Zizka, M., Homolka, L., Knapkova, A. and Pelloneova, N. (2021). Do clustered firms outperform the non-clustered? Evidence of financial performance in traditional industries. Economic Research-Ekonomska Istraživanja, https://doi.org/10.1080/1331677X.2021.1874460 
30. Rogito, J. M., Makhanu, E., Mombinya, B. K. and Nyamota, G. (2020), Relationship between access to financial services and youth involvement in agricultural value chains in Kakamega county, Kenya. Agricultural and Resource Economics, 6(2): 24-36. https://doi.org/10.22004/ag.econ.303855

31. Saban Kumar, K. C. and Timalsina, A. K. (2018). A Case Study on Agro-based E-Commerce Portal. International Journal of Environment Agriculture and Biotechnology, 3(1): 213-216. https://doi.org/10.22161/ijeab/3.1.27

32. Sbardella, A., Pugliese, E., Zaccaria, A. and Scaramozzino, P. (2018). The Role of Complex Analysis in Modelling Economic Growth. Entropy, 20. https://doi.org/10.3390/e20110883

33. Shevchenko, A. and Petrenko, O. (2020). Current state of micro and small agribusiness in Ukraine. Agricultural and Resource Economics, 6(1): 146-160. https://doi.org/10.51599/are.2020.06.01.10

34. Sitnicki, M. and Netreba, I. (2020). Interdependence assessing for networked readiness index economic and social informative factors. Baltic Journal of Economic Studies, 6(2): 47-53. https://doi.org/10.30525/2256-0742/2020-6-2-47-53

35. Sumets, A., Kniaz, S. Heorhiadi, N., Farat, O., Skrynkovskyy, R. and Martyniuk, V. (2021). Methodical approach to the selection of options for ensuring competitiveness of enterprises in the system of development of agricultural clusters. Agricultural and Resource Economics, 7(1): 192-210. https://doi.org/10.51599/are.2021.07.01.10

36. Sumets, A., Serbov, M., Skrynkovskyy, R., Faldyna, V. and Satusheva, K. (2020). Analysis of influencing factors on the development of agricultural enterprises based on e-commerce technologies. Agricultural and Resource Economics, 6(4): 211-231. https://doi.org/10.51599/are.2020.06.04.11

37. Vedeneev, V. A. (2019). Evaluation of the effectiveness of long-term models for forecasting the selling price of agricultural products in Ukraine. Economy and state, 9: 46-51. https://doi.org/10.32702/2306-6806.2019.9.46

38. Wardhana, D., Ihle, R. and Heijman, W. (2017). Agro-clusters and Rural Poverty: A Spatial Perspective for West Java. Bulletin of Indonesian Economic Studies, 53(2): 161-186. https://doi.org/10.1080/00074918.2017.1298722

39. Watkins, M. W. (2018). Exploratory Factor Analysis: A Guide to Best Practice. Journal of Black Psychology, 44(3): 219-246. https://doi.org/10.1177/0095798418771807 